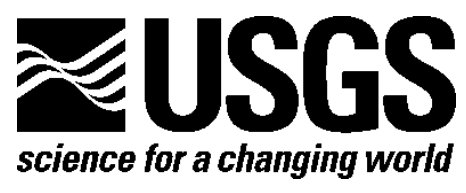

Prepared in cooperation with the New England Interstate Water Pollution Control Commission and the Vermont Department of Environmental Conservation

\title{
Concentration, Flux, and Trend Estimates With Uncertainty for Nutrients, Chloride, and Total Suspended Solids in Tributaries of Lake Champlain, 1990-2014
}

By Laura Medalie

Open-File Report 2016-1200

U.S. Department of the Interior

U.S. Geological Survey 


\section{U.S. Department of the Interior \\ SALLY JEWELL, Secretary}

\section{U.S. Geological Survey \\ Suzette M. Kimball, Director}

U.S. Geological Survey, Reston, Virginia: 2016

For more information on the USGS-the Federal source for science about the Earth,
its natural and living resources, natural hazards, and the environment-visit
http://www.usgs.gov/ or call 1-888-ASK-USGS (1-888-275-8747).

For an overview of USGS information products, including maps, imagery, and publications, visit http://store.usgs.gov/.

Any use of trade, firm, or product names is for descriptive purposes only and does not imply endorsement by the U.S. Government.

Although this information product, for the most part, is in the public domain, it also may contain copyrighted materials as noted in the text. Permission to reproduce copyrighted items must be secured from the copyright owner.

Suggested citation:

Medalie, Laura, 2016, Concentration, flux, and trend estimates with uncertainty for nutrients, chloride, and total suspended solids in tributaries of Lake Champlain, 1990-2014: U.S. Geological Survey OpenFile Report 2016-1200, 22 p., https://doi.org/10.3133/ofr20161200.

ISSN 2331-1258 (online) 


\section{Contents}

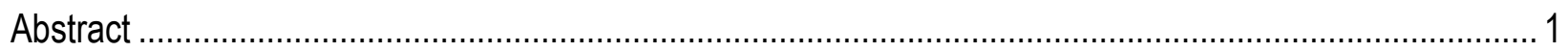

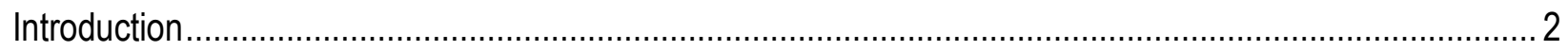

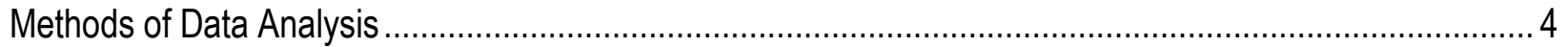

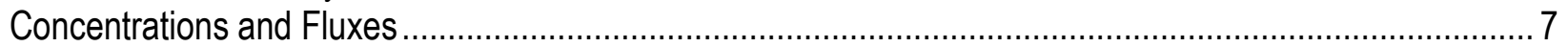

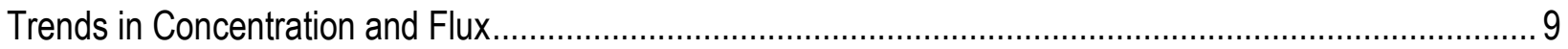

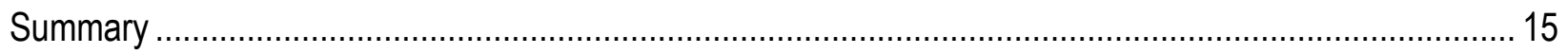

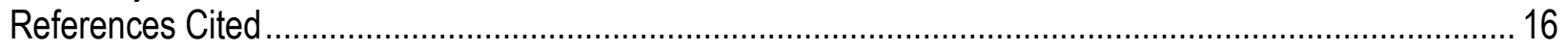

\section{Figures}

1. Map showing Lake Champlain Basin, water-quality monitoring stations and streamgages, and boundaries of the monitored basins of tributaries to Lake Champlain

2. Representative plots of estimated in relation to observed fluxes on sampled days for Weighted Regression on Time, Discharge, and Season models with high flux bias statistics for Lake Champlain from 1990 through 2014

3. Graphs showing 9-month estimated and flow-normalized average daily concentrations of total phosphorus for the 18 monitored tributaries of Lake Champlain from 1990 through 2014

4. Graphs showing 9-month estimated and flow-normalized average daily flux of total phosphorus for the 18 monitored tributaries of Lake Champlain from 1990 through 2014

5. Graphs showing estimates of annual total phosphorus concentrations for the Winooski River, Vertmont.

\section{Tables}

1. Station identifiers and start and end dates of daily and 9-month estimates and of trend period for concentration and flux of total and dissolved phosphorus, chloride, total nitrogen, and total suspended solids for 18 monitored tributaries of Lake Champlain

2. Flux bias statistics comparing the Weighted Regression on Time, Discharge, and Season regression model estimates with water-quality observations for total and dissolved phosphorus, total nitrogen, chloride, and total suspended solids for tributaries to Lake Champlain.

3. Average fraction of annual flux contributed during winter months for tributaries to Lake Champlain20

4. Trend estimates for concentration of total and dissolved phosphorus, total nitrogen, chloride, and total suspended solids for two time periods, and trend probabilities between 1991 (or 1993) and 2014 for tributaries to Lake Champlain

5. Trend estimates for flux of total and dissolved phosphorus, total nitrogen, chloride, and total suspended solids for two time periods, and trend probabilities between 1991 (or 1993) and 2014 for tributaries to Lake Champlain 


\section{Conversion Factors}

International System of Units to U.S. customary units

\begin{tabular}{lcl}
\hline \multicolumn{1}{c}{ Multiply } & By & \multicolumn{1}{c}{ To obtain } \\
\hline kilometer $(\mathrm{km})$ & 0.6214 & mile $(\mathrm{mi})$ \\
square kilometer $\left(\mathrm{km}^{2}\right)$ & 0.3861 & square mile $\left(\mathrm{mi}^{2}\right)$ \\
cubic meter per second $\left(\mathrm{m}^{3} / \mathrm{s}\right)$ & 35.31 & cubic foot per second $\left(\mathrm{ft}^{3} / \mathrm{s}\right)$ \\
kilogram per day $(\mathrm{kg} / \mathrm{d})$ & 2.205 & pound per day $(\mathrm{lb} / \mathrm{d})$ \\
metric ton $(\mathrm{t})$ & 1.102 & ton, short $[2,000 \mathrm{lb}]$ \\
\hline
\end{tabular}

\section{Datum}

Horizontal coordinate information is referenced to the North American Datum of 1983 (NAD 83).

\section{Supplemental Information}

Concentrations of chemical constituents in water are given in milligrams per liter (mg/L).

\section{Abbreviations}

$\begin{array}{ll}\text { EGRET } & \text { Exploration and Graphics for RivEr Trends } \\ \text { EGRETci } & \text { Exploration and Graphics for RivEr Trends, confidence intervals } \\ \text { EPA } & \text { U.S. Environmental Protection Agency } \\ \text { FN } & \text { flow normalization } \\ \text { NWIS } & \text { National Water Information System } \\ \text { STORET } & \text { STOrage and RETrieval } \\ \text { TSS } & \text { total suspended solids } \\ \text { USGS } & \text { U.S. Geological Survey } \\ \text { WRTDS } & \text { Weighted Regressions on Time, Discharge, and Season regression model }\end{array}$




\title{
Concentration, Flux, and Trend Estimates With Uncertainty for Nutrients, Chloride, and Total Suspended Solids in Tributaries of Lake Champlain, 1990-2014
}

\author{
By Laura Medalie
}

\begin{abstract}
The U.S. Geological Survey, in cooperation with the New England Interstate Water Pollution Control Commission and the Vermont Department of Environmental Conservation, estimated daily and 9-month concentrations and fluxes of total and dissolved phosphorus, total nitrogen, chloride, and total suspended solids from 1990 (or first available date) through 2014 for 18 tributaries of Lake Champlain. Estimates of concentration and flux, provided separately in Medalie (2016), were made by using the Weighted Regressions on Time, Discharge, and Season (WRTDS) regression model and update previously published WRTDS model results with recent data. Assessment of progress towards meeting phosphorus-reduction goals outlined in the Lake Champlain management plan relies on annual estimates of phosphorus flux. The percent change in annual concentration and flux is provided for two time periods. The R package EGRETci was used to estimate the uncertainty of the trend estimate. Differences in model specification and function between this study and previous studies that used WRTDS to estimate concentration and flux using data from Lake Champlain tributaries are described.

Winter data were too sparse and nonrepresentative to use for estimates of concentration and flux but were sufficient for estimating the percentage of total annual flux over the period of record. Median winter-to-annual fractions ranged between 21 percent for total suspended solids and 27 percent for dissolved phosphorus. The winter contribution was largest for all constituents from the Mettawee River and smallest from the Ausable River.

For the full record (1991 through 2014 for total and dissolved phosphorus and chloride and 1993 through 2014 for nitrogen and total suspended solids), 6 tributaries had decreasing trends in concentrations of total phosphorus, and 12 had increasing trends; concentrations of dissolved phosphorus decreased in 6 and increased in 8 tributaries; fluxes of total phosphorus decreased in 5 and increased in 10 tributaries; and fluxes of dissolved phosphorus decreased in 4 and increased in 10 tributaries (where the number of increasing and decreasing trends does not add up to 18, the remainder of tributaries had no trends). Concentrations and fluxes of nitrogen decreased in 10 and increased in 4 tributaries and of chloride decreased in 2 and increased in 15 tributaries. Concentrations of total suspended solids decreased in 4 and increased in 8 tributaries, and fluxes of total suspended solids decreased in 3 and increased in 11 tributaries.

Although time intervals for the percent changes from this report are not completely synchronous with those from previous studies, the numbers of and specific tributaries with overall negative percent changes in concentration and flux are similar. Concentration estimates of total phosphorus in the Winooski River were used to trace whether changes in trends between a previous study and the current study were due generally to differences in model specifications or differences from 4 years of additional
\end{abstract}


data. The Winooski River analysis illustrates several things: that keeping all model specifications equal, concentration estimates increased from 2010 to 2014; the effects of a smoothing algorithm used in the current study that was not available previously; that narrowing model half-window widths increased year-to-year variations; and that the change from an annual to a 9-month basis by omitting winter estimates changed a few individual points but not the overall shape of the flow-normalized curve. Similar tests for other tributaries showed that the primary effect of differences in model specifications between the previous and current studies was perhaps to increase scatter over time but that changes in trends generally were the result of 4 years of additional data rather than artifacts of model differences.

\section{Introduction}

The U.S. Geological Survey (USGS), in cooperation with the New England Interstate Water Pollution Control Commission and the Vermont Department of Environmental Conservation, used data from an extensive water-quality and streamflow monitoring program for tributaries to Lake Champlain (fig. 1), which began in 1990 (Vermont Department of Environmental Conservation and New York

State Department of Environmental Conservation, 2015), to estimate concentration and flux of total and dissolved phosphorus, total nitrogen (hereafter "nitrogen"), chloride, and total suspended solids (TSS) through 2014 (except for at two sites, for which data collection ended September 30, 2014, and annual estimates are through 2013; hereafter, the ending date for trends is referred to as "through 2014"). These estimates at the daily and annual time steps can be used for numerous modeling and analytical purposes. A primary use of the phosphorus estimates is to evaluate progress towards one of the fundamental goals of the Lake Champlain "Opportunities for Action" management plan (Lake Champlain Basin Program, 2014): to reduce phosphorus loads entering Lake Champlain from its tributaries.

This report describes methods used to produce daily and annual concentration and flux estimates by means of the Weighted Regressions on Time, Discharge, and Season (WRTDS) regression model (Hirsch and others, 2010) for the 18 Lake Champlain tributaries with long-term water-quality and streamgaging records. Daily and annual estimates are provided in Medalie (2016). The estimates update previously published data of WRTDS model results for these Lake Champlain tributaries (Medalie and others, 2012; Medalie, 2013; Medalie, 2014). The percent change in annual concentration and flux between the beginning and the end of the record provides a measure of the trend. Uncertainty in the trend estimate is presented as an estimate of the statistical probability or likelihood of an increasing or decreasing trend. 


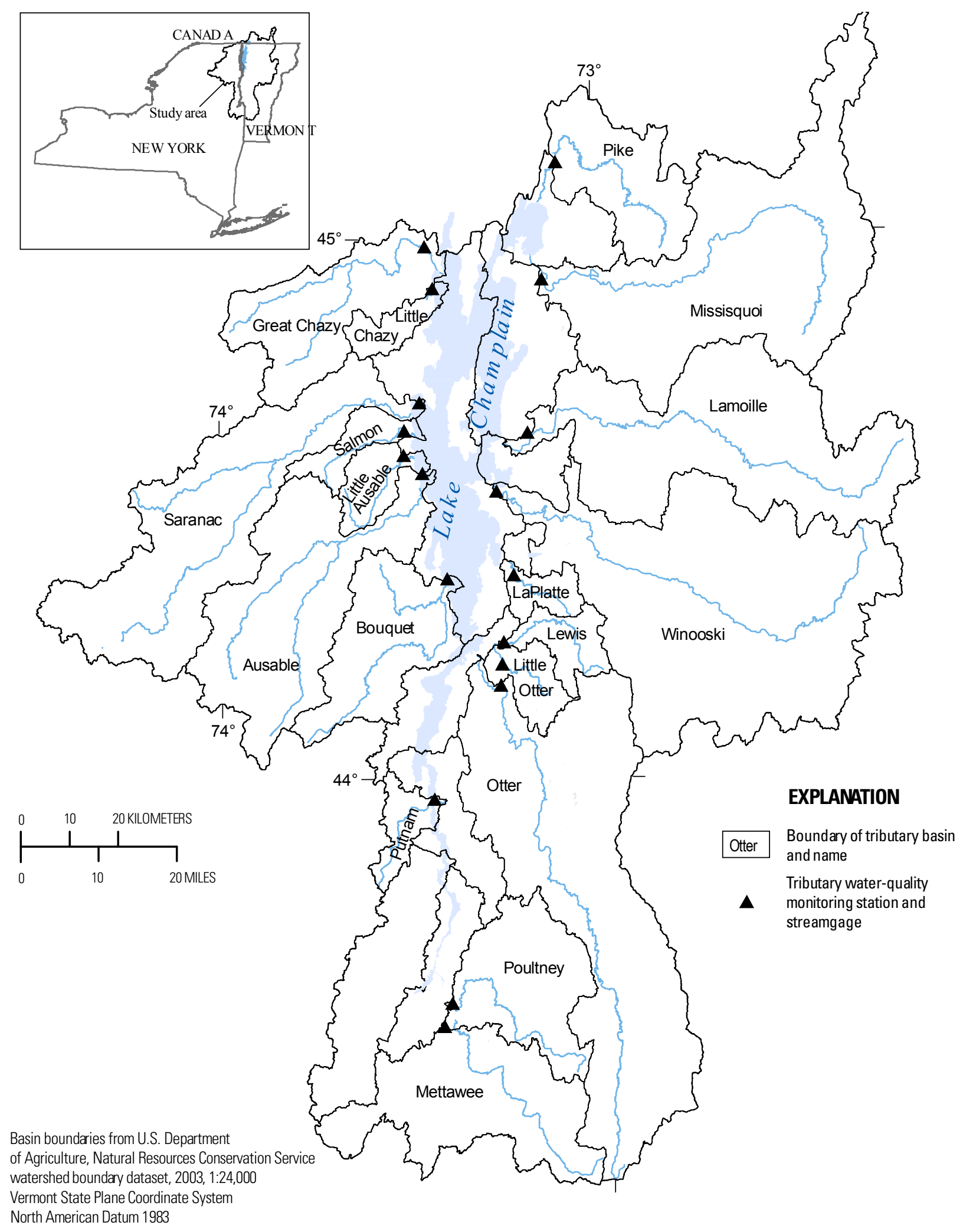

Figure 1. Map showing Lake Champlain Basin, water-quality monitoring stations and streamgages, and boundaries of the monitored basins of tributaries to Lake Champlain. Figure modified from Medalie (2013). 


\section{Methods of Data Analysis}

WRTDS models, produced by the R package EGRET (Exploration and Graphics for RivEr Trends; Hirsch and De Cicco, 2014), were used to estimate daily and annual concentration and flux of total and dissolved phosphorus, nitrogen, chloride, and total suspended solids for Lake Champlain tributaries. Several publications describe the theoretical basis, calculations, use, and limitations of WRTDS and compare it to other regression-based estimation methods (Hirsch and others, 2010; Moyer and others, 2012; Hirsch, 2014; and Hirsch and De Cicco, 2014). Concentration and flux estimates from WRTDS were calculated and presented in two ways. The first way bases the estimate for each day in the record on the observed discharge for the given day. The second way, called flow normalization (FN), calculates the mean of estimates made for a given day by using each discharge value in the record for the day. ${ }^{1} \mathrm{FN}$ estimates remove effects of natural variability in discharge that could obscure the authentic signal of water-quality change in unadjusted observations. A measure of WRTDS model fit is provided by the flux bias statistic [[mean (predicted flux) - mean (observed flux)] / mean (observed flux)]; values of the flux bias statistic between -0.1 and +0.1 indicate an acceptable model, and values beyond that range indicate a possible problem (Hirsch, 2014).

Most of the methods of data collection, data analysis, and the application of WRTDS to Lake Champlain tributary data are similar to those documented in Medalie (2013). Departures are noted in this section. The Vermont Department of Environmental Conservation collects water samples from 22 Lake Champlain tributaries, analyzes them for water quality, and uploads results to the U.S. Environmental Protection Agency (EPA) STOrage and RETrieval (STORET) database. The 18 tributaries with at least a 20 -year record, the minimum period of record that is recommended for use of WRTDS, are analyzed in this report.

Not done previously for Lake Champlain datasets, discharge and water-quality data were mined for use in EGRET directly from online databases (the National Water Information System [NWIS; https://doi.org/10.5066/F7P55KJN] for discharge [except for Pike River] and STORET for water quality via the Water Quality Portal [http://www.waterqualitydata.us/]), eliminating formatting steps (table 1). Retrievals of water-quality data from STORET were made by using the command "readWQPqw" from the R dataRetrieval package (Hirsch and De Cicco, 2014), with station identifiers given in table 1 and chemical parameters specified by the characteristic names "Phosphorus," "Nitrogen," "Chloride," and "Total suspended solids." In a subsequent step, phosphorus was differentiated by "Total" or "Dissolved" fraction. The average number of samples used to develop the WRTDS models was 434 for total phosphorus, 308 for dissolved phosphorus, 226 for nitrogen, 317 for chloride, and 237 for total suspended solids. Annually, the number of samples collected from each station ranged from 14 to 19 for total phosphorus and from 5 to 16 for the other constituents.

Daily discharges for 17 of the tributaries were obtained directly from NWIS. Daily discharge data for the remaining site, the Pike River streamgage in Canada, were obtained online from the Québec Ministère du Développement durable, de l'Environnement et de la Lutte contre les changements climatiques (2015) Web site and reformatted before manual input to the WRTDS model. Duplicating a method used previously (Medalie, 2014), adjusted discharge data for January 1, 1990, through October 31, 2001, from the original Pike River streamgage (030420), which was discontinued in 2012, were concatenated with discharge data for November 1, 2001, through December 31, 2014, from the replacement streamgage (030424), 13 kilometers downstream on the Pike River. The adjustment to

\footnotetext{
${ }^{1}$ For instance, the FN estimate of concentration for May 1, 2010, is the mean of estimates made from regression equations that use each observed May 1st discharge value in the record as the independent variable discharge.
} 
discharge data from streamgage 030420 for the record through October 31, 2001, involved multiplying discharge by the drainage-area ratio between the two streamgages (404 square kilometers $\left[\mathrm{km}^{2}\right]$ for 030420 and $584 \mathrm{~km}^{2}$ for 030424 ). Daily discharges in units of cubic meters per second for all 18 streamgages for the period covered in this report are included with tables of daily estimates in Medalie (2016).

Because most discharge data were retrieved directly from online databases rather than input manually, records for 11 stations that began operations on March 1, 1990, and the Little Ausable River station that began operations October 1991 were not extended with estimates to cover the period between January 1 and February 28, 1990 (table 1), as was done for previous publications (Medalie and others, 2012; Medalie, 2014). Because sampling for nitrogen and TSS began in June 1992 or shortly thereafter for all stations, the first year of estimates of concentration and flux and the start date of trends for these constituents is 1993, and daily estimates begin June 1, 1992. Estimates of concentration and flux for 1990 can be obtained online (Medalie, 2014). Because the Little Chazy River and Putnam Creek streamgages were discontinued in water year 2015, the last day of daily estimates for both stations is September 30, 2014, and the last year of annual estimates and the trend period is 2013.

Several changes are implemented in the latest version of the EGRET software that runs the WRTDS model (EGRET version 2.3.1, documented for generic version 2.0 in Hirsch and De Cicco, 2014) and were not in versions used for previous estimates for Lake Champlain. ${ }^{2}$ Although an infrequent feature of these Lake Champlain data, the newest software accommodates left- or intervalcensored data using survival regression; left-censored data include water-quality results that are less than analytical detection limits. Another change in WRTDS is availability of a smoothing algorithm called edgeAdjust that reduces edge effects of the weighting procedure near the beginning and end of the record (Hirsch and De Cicco, 2014). EdgeAdjust causes the window width for year to gradually widen at both ends of the record and to narrow in the middle years, reducing the disproportionate influence of observations according to their positions in the time record. Before the edgeAdjust algorithm was available, greater changes in estimates near the ends of the record were expected as additional years of data were collected (Hirsch and others, 2010).

In addition to changes in software, a few differences in methodology compared to that used for previous Lake Champlain estimates need to be mentioned. One difference involves the user-specified half-window widths, model parameters for time, discharge, and season used in the regression equation. The default half-window width for time changed from 10 to 7 years. Default values of 7 years for time and 2 logarithmic cycles for discharge are strongly recommended by Hirsch and De Cicco (2014) and are used for all regression models in this analysis. In Medalie (2013), the half-window widths for year ranged from 10 to 30 and for discharge ranged from 2 to 4.

The window width for season, however, is narrowed from the default of 0.5 to 0.25 of a year for this application of WRTDS to the Lake Champlain data. In Medalie (2013), the half-window width for season ranged from 0.5 to 1 . A close look at the Lake Champlain data suggests that the frequency and type of sample data from winter months are inadequate for making meaningful wintertime estimates of concentration and flux (Robert M. Hirsch, USGS, written commun., October 30, 2015). Over the period of record, the sampling frequency for total phosphorus during winter (December through February) ranged among stations from about 0.2 to 0.4 samples per month, whereas during the rest of the year it ranged from 1.7 to 2.2 samples per month. Frequencies are also lowest during winter for the other constituents. Furthermore, the few available winter samples do not cover the full range of discharges.

\footnotetext{
${ }^{2}$ Various forms of version 1 were used for previous applications of WRTDS to data from Lake Champlain tributaries. Most recently, EGRET version 1.2.4 was used (Medalie, 2014).
} 
Samples are collected only at high discharges during thaws or rain events, as sample collection is not feasible during typical winter conditions when rivers are covered by snow and ice (Vermont Department of Environmental Conservation and New York State Department of Environmental Conservation, 2015, p. 62). The narrowing of window width for season serves to decrease the influence (by lowering weights in the regression) of data from the sparsely sampled winter months that do not represent the full range of hydrologic conditions.

Estimates made in WRTDS, like all regression model estimates, tend to be more biased when extrapolations are made beyond the data (Hirsch, 2014). Consequently, an additional accommodation of sparse winter samples at only high flows was to adjust the period of estimation in order to reduce extrapolations beyond available data. For this change of execution from previous estimates, daily estimates of concentration and flux presented in this report and in Medalie (2016) are provided only for the 9-month reporting period of March through November (Robert M. Hirsch, USGS, written commun., October 30, 2015). Furthermore, annual estimates of concentration and flux are not provided in Medalie (2016). Instead, the 9-month reporting period of March through November is the substitute period for annual estimates of concentration and flux and is the period over which trends are calculated. This is a departure from previous reports on Lake Champlain tributaries, which used a standard 12-month calendar-year reporting period for annual estimates of concentration and flux (Medalie and others, 2012; Medalie, 2014). Daily estimates of concentration, normally averaged over the year to produce annual estimates of concentration, are instead averaged over the period of March through November for this report. Daily estimates of flux, previously summed over the year to produce annual estimates of flux, are averaged over the period of March through November for this report.

To underscore the change to a 9-month reporting period from previous reporting (Medalie and others, 2012; Medalie, 2014) based on a 12-month period, and to prevent the inadvertent comparison of results that are not meant to be compared (annual estimates of concentration and flux from previous reports with 9-month estimates from Medalie [2016]), the 9-month flux is presented in Medalie (2016) as an average rather than a sum. In other words, previous reports provided total flux for each year in the record; this report provides average daily flux over the 9-month period for each year. The difference in values is approximately two orders of magnitude (equal to the factor 365). Whereas flux is not directly comparable, annual estimates of concentrations presented in previous reports have qualified comparability to 9-month estimates of concentrations presented in Medalie (2016). Both estimates of concentration are averages of daily values, and units are the same. In the case of previous reports, concentrations are averaged over 12 months of the year, whereas in Medalie (2016), concentrations are averaged over 9 months. Although the difference between estimates of concentration generally is not substantial, it is important to be aware of the different averaging periods.

Although too infrequent to be included in estimates of trend, winter data are sufficient for computation of the average percentage of total annual flux contributed during winter. This computation uses an algorithm (Hirsch, 2015) that allows the user to specify the beginning month and the total number of months of the season for which the percentage of total annual flux is calculated. In this case, the season is winter, the beginning month is December, and the total number of months is 3 . The fraction of annual flux contributed during winter was calculated for each year and averaged over the period of record.

Data from each tributary are investigated for other potentially inappropriate extrapolations based on discharge values from days when samples were not collected at all times of the year, not just winter. For tributaries where the highest discharge value that is coincident with sample collection is less than half the observed discharge for the record, estimates of concentration and flux based on observed discharge are not made for days where the discharge is greater than the maximum discharge value 
coincident with sample collection. Calculations for annual means of concentration and flux are made without these omitted daily values, which tends to have negligible to little effect on the calculation of annual concentrations and negligible effect to moderate underestimation of annual flux. Conversely, estimates of FN concentrations and fluxes are made for all nonwinter days regardless of the discharge because flow normalizing integrates over the entire period of record and minimizes the influence of any individual value.

An important new component of this report is an expression of uncertainty associated with trend estimates for annual FN concentration and flux. The calculation of trend, as the percent change in estimates of concentration or flux between two dates, is not new. Quantification of uncertainty became available for WRTDS-generated estimates in 2015 with the R package EGRETci (Exploration and Graphics for RivEr Trends, confidence intervals) from the Comprehensive R Archive Network (Hirsch and others, 2015). The EGRETci method applies a bootstrap test using Monte Carlo simulations to estimate the type 1 error probability, or the probability of detecting a trend when a trend is not present. Model inputs as suggested by the EGRETci authors (100 bootstrap replicates, 40 or more replicates, and 200 days in a bootstrap block) were used for this analysis. Although EGRETci output includes a $p$-value statistic, trend uncertainty is expressed in terms of the estimate of the probability or likelihood of an increasing or decreasing trend ${ }^{3}$ (Hirsch and others, 2015). Trend results for two water-year periods, from 1991 through 2014 and from 2000 through 2014, are presented as percent changes between the annual estimates of FN concentration and flux for the given dates. Trend probability is provided only for the percent changes from 1991 through 2014.

\section{Concentrations and Fluxes}

Daily and annual estimated and FN concentrations and fluxes of total and dissolved phosphorus and chloride for 1990 through 2014 and of nitrogen and TSS for 1993 through 2014 for the 18 monitored tributaries of Lake Champlain are published in Medalie (2016). Daily estimates from Salmon, Little Ausable, and Poultney Rivers are not provided for the fewer than 10 days for which extremely high discharges are beyond the range of discharges measured when samples were collected.

All of the Lake Champlain tributaries had flux bias statistics of less than \pm 0.1 for chloride and nitrogen, and 2 out of 18 tributaries had flux bias statistics greater than \pm 0.1 for each of total and dissolved phosphorus; thus, 68 out of 72 models for these four constituents had acceptable bias (table 2). Flux bias statistics for TSS tend to be larger than for other constituents in the Lake Champlain tributaries (Medalie, 2014), possibly because of the nonlinear relation between TSS and discharge (Hirsch, 2014). The particularly large flux bias statistic for TSS in the Saranac River is attributable to severe model underestimation for the single day with the largest mean discharge but has little effect on flow-normalized fluxes for most of the record (Medalie, 2014). Plots of observed flux in relation to estimated flux for four models with large flux bias statistics do not show a pervasive lack of symmetry around the 1:1 line on days with highest observed or estimated flux; such a lack of symmetry would provide direct evidence of bias in flux estimates (Hirsch, 2014). Rather, the plots show effects attributable to one or two anomalous values (fig. 2). These plots are generally symmetrical, indicating the potential bias is not substantial (despite the high flux bias statistic). Furthermore, the effect of

\footnotetext{
${ }^{3}$ To use the example given by Hirsch and others (2015), assume the WRTDS bootstrap method shows an upward trend in 80 out of 100 cases. The likelihood of an increasing trend would be 0.8 , yet the $p$ value could be 0.4 , which would result in the failure to reject the null hypothesis of no trend at $\alpha=0.1$. The likelihood probability of 0.8 is arguably a more suitable indicator of trend strength than the $p$-value.
} 
removing outliers would be minimal for estimates based on observed discharges that are distant in time to the outliers and on all FN estimates (Medalie, 2014, fig. 2).
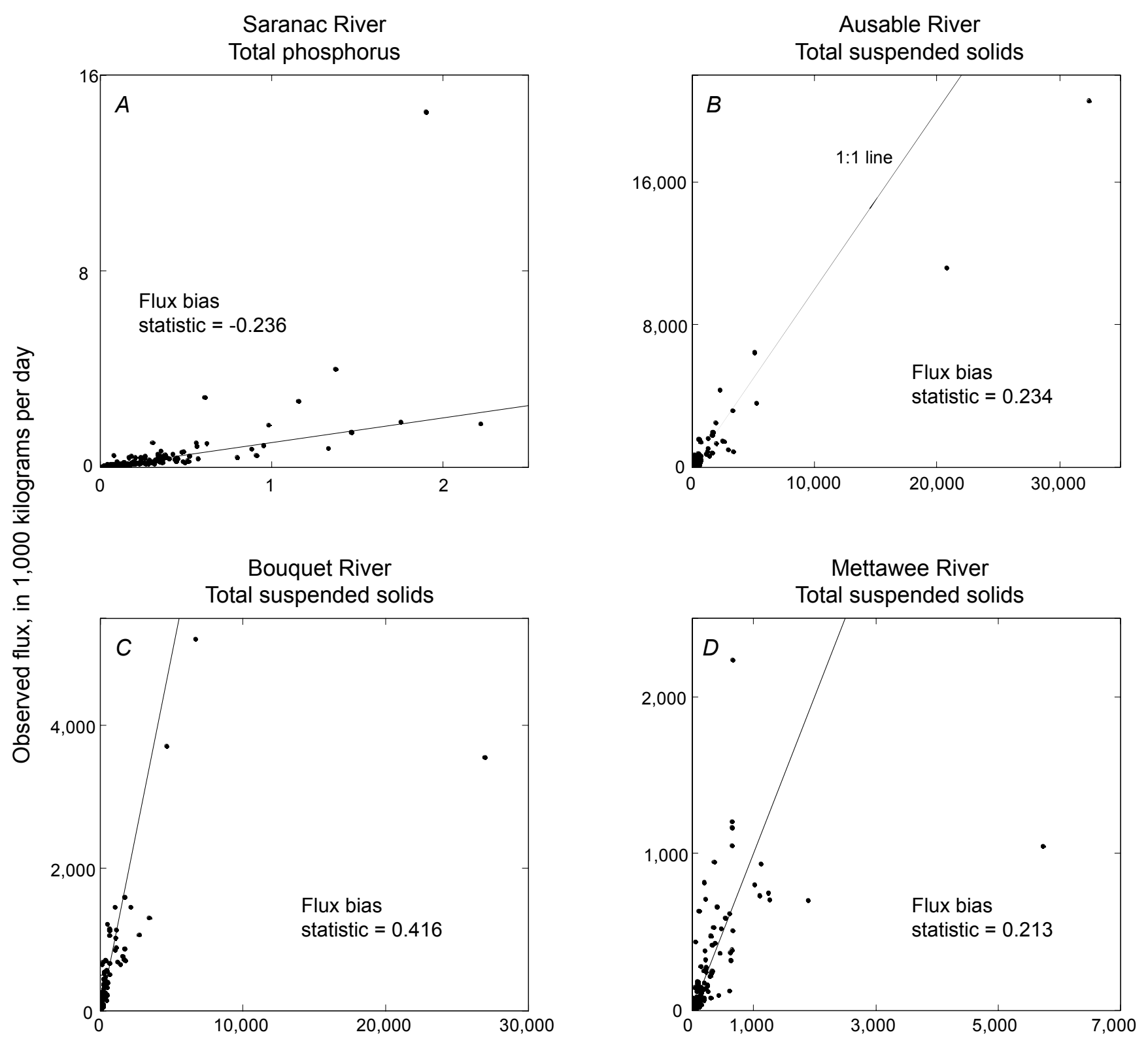

Estimated flux, in 1,000 kilograms per day

Figure 2. Representative plots of estimated in relation to observed fluxes on sampled days for Weighted Regression on Time, Discharge, and Season models with high flux bias statistics: A, total phosphorus for the Saranac River; B, total suspended solids for the Ausable River; C, total suspended solids for the Bouquet River; and D, total suspended solids for the Mettawee River. Data points for plot A include samples between March 1 and November 30 for 1990 through 2014, and data points for plots B, C, and D include samples between March 1 and November 30 for 1992 through 2014. 
Although data were too sparse to make daily or trend estimates for the winter period (December through February), sufficient winter samples exist to determine, averaged over the entire record, the percentage of annual flux that was contributed during winter months (table 3). The median winter-toannual fractions of all tributaries ranged between 21 percent for total suspended solids and 27 percent for dissolved phosphorus. The winter contribution was consistently largest from the Mettawee River for all constituents, and also was large for most constituents from the Poultney River and Otter and Little Otter Creeks. Winter contributions to annual flux were consistently low (less than 22 percent) from the Ausable River and generally low from the Bouquet, Lamoille, and Salmon Rivers.

\section{Trends in Concentration and Flux}

For this discussion, increasing and decreasing trends between 1991 (or 1993) and 2014 are designated by up and down arrows (for probable upward or downward trends) in tables 4 and 5 . The positive or negative sign of the percent change per year indicates "apparent" (as distinguished from statistically significant) increases or decreases. The percent change between any 2 years is calculated on the basis of the annual (9-month) estimates produced by the WRTDS model (in other words, WRTDS is not run separately to produce percent changes for different combinations of years). Trends for total phosphorus concentration (fig. 3) and flux (fig. 4) also are illustrated by plots of 9-month estimated values with and without flow normalization.

This section begins with a summary of trend directions for concentrations and fluxes of all constituents. Next, differences in percent changes per year are given for two time periods (the full record, between 1991 and 2014; and the recent record, between 2000 and 2014) in order to highlight the largest contrasts in direction and magnitude of percent changes between the time periods. The section concludes with a comparison of trend estimates in tables 4 (for concentration) and 5 (for flux) of this report with trend estimates in tables 3 (for concentration) and 4 (for flux) of Medalie (2013).

Between 1991 and 2014, 6 tributaries had decreasing trends in concentrations of total phosphorus, and 12 had increasing trends; 6 had decreasing trends in concentrations of dissolved phosphorus, and 8 had increasing trends (4 had no trend). Concentrations of nitrogen, for which data were available beginning in 1993, decreased in 10 tributaries and increased in 4 tributaries (4 had no trend) between 1993 and 2014. Two tributaries had decreasing trends in concentrations of chloride, and 15 had increasing trends ( 1 had no trend) between 1991 and 2014 (table 4). Concentrations of TSS decreased in 4 and increased in 8 tributaries ( 6 had no trend).

Decreasing trends in total phosphorus flux (table 5) between 1991 and 2014 were seen in 5 tributaries and increasing trends in 10 (3 had no trend); decreasing trends in dissolved phosphorus flux were seen in 4 tributaries and increasing trends in 10 (4 had no trend). Between 1993 and 2014, decreasing trends in nitrogen flux were observed in 10 tributaries and increasing trends in 4 ( 4 had no trend). Decreasing trends in chloride flux were seen in 2 tributaries and increasing trends in 15 ( 1 had no trend). Decreasing trends in TSS flux were seen in 3 tributaries, and increasing trends were seen in 11 (4 had no trend). 

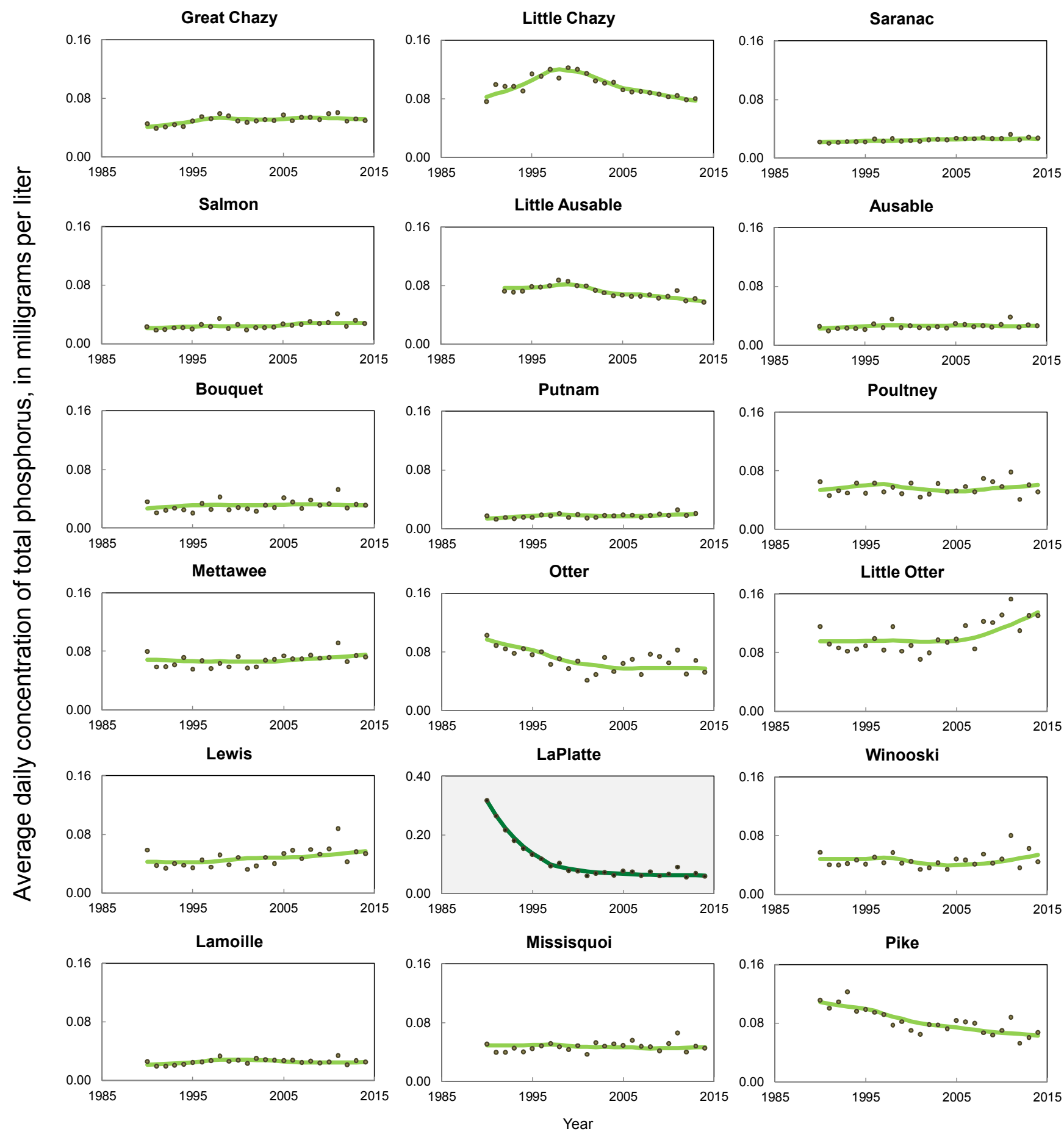

Figure 3. Graphs showing 9-month estimated (brown dots) and flow-normalized (green lines) average daily concentrations of total phosphorus for the 18 monitored tributaries of Lake Champlain from 1990 through 2014. The $y$-axis scale is different for the LaPlatte River plot than for the rest of the plots. 

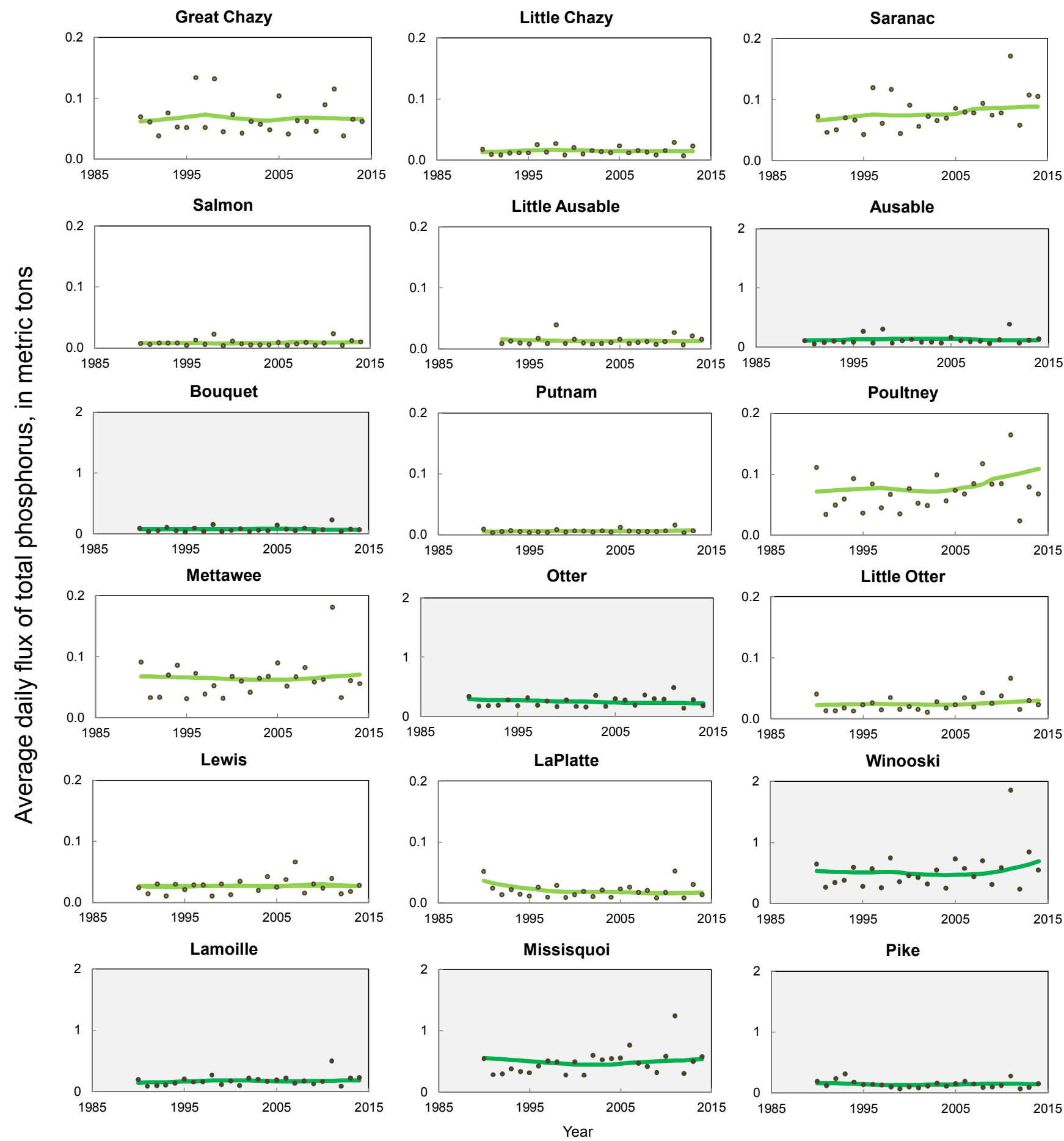

Figure 4. Graphs showing 9-month estimated (brown dots) and flow-normalized (green lines) average daily flux of total phosphorus for the 18 monitored tributaries of Lake Champlain from 1990 through 2014. The y-axis scales are different for the shaded plots than for the rest of the plots. 
This discussion highlights the largest differences in percent change between the full record (1991 through 2014) and the recent record (2000 through 2014), For total phosphorus concentrations (table 4), a positive percent change in the Lamoille River for the full record became a negative percent change for the recent record. Similar (but lesser magnitude) positive percent changes in the full records that changed to negative percent changes in the recent record occurred in the Great Chazy, Ausable, and Bouquet Rivers; a negative percent change in the Little Chazy River for the full record grew more negative by a factor of 5 in the recent record; and although no tributaries reversed change direction from negative to positive, the LaPlatte River negative percent change diminished and the Little Otter Creek positive percent change increased in the recent record compared to the full record. Total phosphorus flux (table 5) with positive percent changes in the Great Chazy, Little Chazy, and Ausable Rivers for the full record shifted to negative percent changes in the recent record; and the reverse, negative percent changes in flux for the full record that shifted to positive percent changes in the recent record, occurred in the Missisquoi and Pike Rivers. The negative percent change in flux in the LaPlatte River decreased in magnitude and positive percent change in flux in the Winooski River increased in magnitude in the recent record compared to the full record.

Positive percent changes in concentrations of dissolved phosphorus (table 4) seen in the full record became negative percent changes in the recent record in the Great Chazy and Salmon Rivers; the negative percent change in the Winooski River became a positive percent change in the recent period; the negative percent change in the Little Chazy River grew more negative and the positive percent change in the Mettawee River diminished in magnitude in the recent period compared to the full record; and the negative percent change in Otter Creek diminished in magnitude in the recent record compared to the full record. Positive percent changes in dissolved phosphorus flux (table 5) in the Great Chazy and Little Chazy Rivers for the full record shifted to negative percent changes in the recent record. Negative percent changes in flux of dissolved phosphorus in the full record that shifted to positive percent changes in the recent record occurred in Otter and Lewis Creeks and the Winooski River. Magnitudes of the negative percent change in the LaPlatte River and of the positive percent change in the Bouquet River diminished in the recent records compared to the full records for flux of dissolved phosphorus.

Nearly all nitrogen and chloride concentrations and fluxes (tables 4 and 5) improved or did not deteriorate in the recent period compared with the full period, in that most negative percent changes stayed negative and most positive percent changes diminished in magnitude or became negative. For nitrogen, the greatest changes for both concentration and flux were seen in the Pike River, where the magnitudes of the negative percent changes grew in the recent period compared to the full period. For chloride, the greatest change was seen in the Ausable River, also for both concentration and flux, where the magnitudes of the positive percent changes diminished in the recent period compared to the full period.

TSS concentrations (table 4) that had positive percent changes in the Great Chazy and Pike Rivers for the full record shifted to negative percent changes in the recent record, and negative percent changes in the full record that shifted to positive percent changes in the recent record occurred in the Mettawee and Missisquoi Rivers. The magnitude of the positive percent change in Lewis Creek diminished twofold and that in the Winooski River increased threefold in the recent records compared to the full records for TSS concentration. A positive percent change in TSS flux (table 5) in the Great Chazy River for the full record shifted to a negative percent change in the recent record. Magnitudes of the positive percent changes in Lewis Creek and the Pike River diminished twofold and threefold, respectively, in the recent records compared to the full records for TSS flux. 
Caution must be used in comparing percent changes from this report with those from previous studies (Medalie, 2013) because the time intervals are not completely synchronous. The "recent period" is 2000 through 2014 for this report and was 2000 through 2010 for the previous report (Medalie, 2013). The "long-term or full record period" is 1991 through 2014 for this report and was 1990 through 2010 for the previous report (Medalie, 2013). Magnitudes and directions of annual percent changes rather than trend results from this study are compared to those from previous studies because trend results from the EGRETci function were not available previously. The numbers of tributaries with negative percent changes in concentration for the full records are very similar ( 7 and 6 tributaries with negative percent changes for total phosphorus for the previous and the current studies, respectively; 5 and 6 with negative percent changes for dissolved phosphorus for the previous and the current studies; 14 and 13 with negative percent changes for total nitrogen for the previous and the current studies; and 2 with negative percent changes for chloride for both studies). TSS was not evaluated in Medalie (2013). The individual tributaries that make up the total numbers with negative percent changes are generally similar for both studies: for total phosphorus, 4 are the same tributaries; for dissolved phosphorus, 4 also are the same; for total nitrogen, 12 are the same; and for chloride, both are the same.

Because phosphorus reduction is featured prominently in the Lake Champlain management plan (Lake Champlain Basin Program, 2014), it is worthwhile to look more closely at some of the total phosphorus trends. In particular, are long-term trends that reversed direction between the previous study (Medalie, 2013) and the current study most likely to be attributable to (1) the addition of 4 years of data analyzed in the current study, (2) differences in the model parameters (half-window widths or use of the edgeAdjust algorithm), or (3) differences due to the omission of the winter period from estimates of concentration and flux for the current study? To answer that question, a visual comparison was made of plots generated in various combinations of ways to test the changes in model parameters.

Concentrations from the Winooski River were used as an example (fig. 5). Adding 4 additional years of data but keeping all model parameters constant showed that concentrations increased from 2010 to 2014 (figs. $5 A$ to $5 B$ ). Using the edgeAdjust algorithm smoothed the $\mathrm{FN}$ data near the beginning and end of the record but otherwise had minimal effect on the data (figs. $5 B$ to $5 C$ ). Narrowing the half-window widths increased scatter (figs. $5 C$ to $5 D$ ). The change from an annual to a 9-month basis made by omitting winter estimates changed a few individual points but not the overall shape of the FN curve (figs. $5 D$ to $5 E$ ).

Similar testing of other tributaries likewise showed that the effect of decreasing half-window widths and omitting 3 months from annual estimates of concentration and flux was generally to increase scatter over time (for both non-FN and FN estimates). The inclusion of 4 more years of data than in previous studies resulted, for some of the tributaries, in reversals of trend direction (Medalie, 2013). An investigation of selected individual tributaries showed that long-term increases from this study in concentrations of total phosphorus in the Poultney and Winooski Rivers and Little Otter Creek and increases in flux of total phosphorus in Putnam Creek and the Mettawee, Winooski, and Pike Rivers that were not seen as increases in the overall period (1990 through 2010) of the previous study (Medalie, 2013) appear to be based, for the most part, on real increases in estimates of concentration or flux between 2010 and 2014 and are not artifacts of differences in model specifications. 

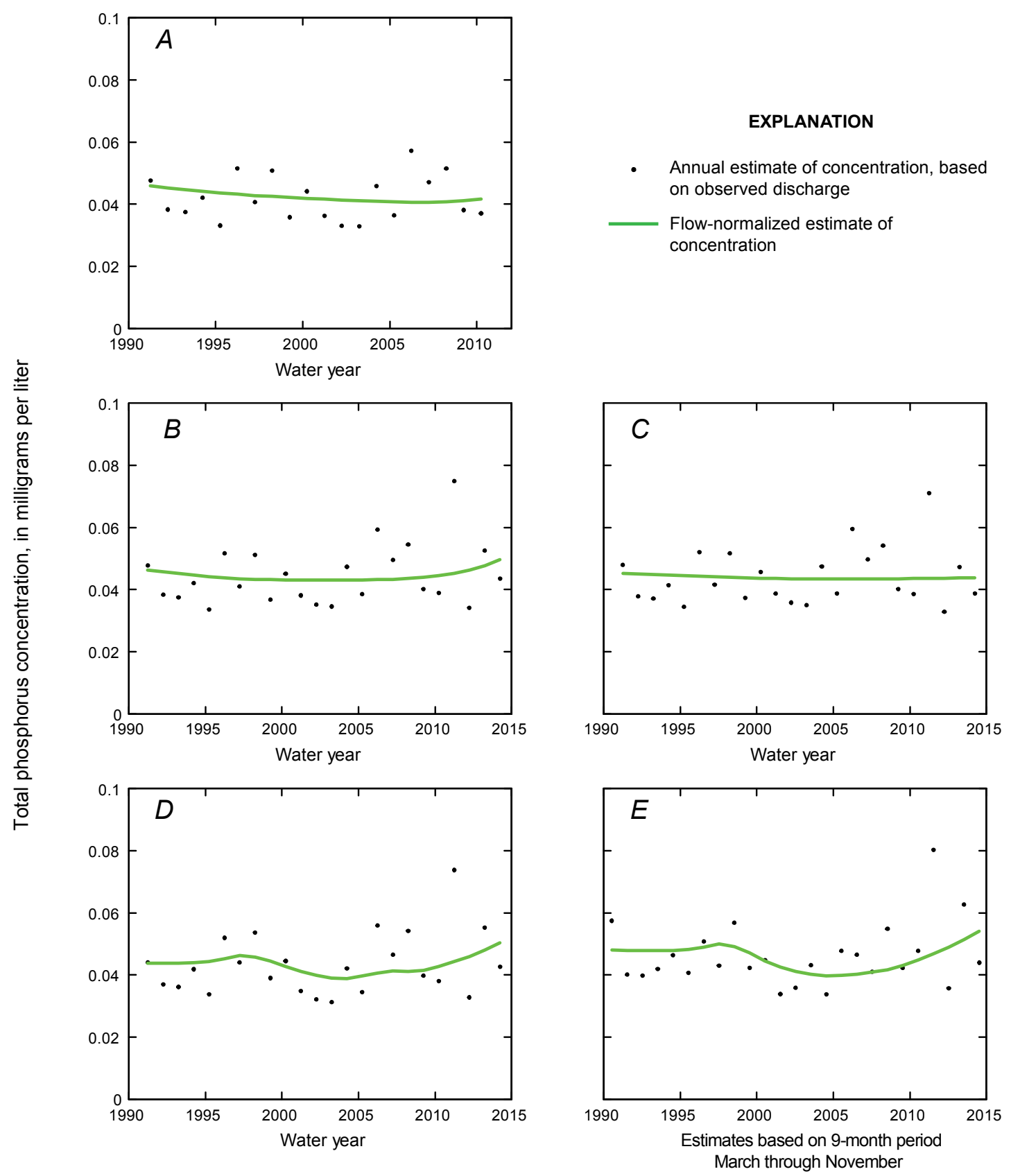

Figure 5. A series of graphs of estimates of annual total phosphorus concentrations for the Winooski River, with and without flow normalization, showing a progression of changes in model (Weighted Regression on Time, Discharge, and Season) parameters from analysis in Medalie (2013) to the current study: A, data are from 1991 through 2010 and half-window widths are wide; B, data are from 1991 through 2014 and half-window widths are wide; C, data are from 1991 through 2014, half-window widths are wide, and edgeAdjust option (Hirsch and De Cicco, 2014) was used; D, data are from 1991 through 2014, half-window widths are narrow, and edgeAdjust option was used; and E, data are from 1991 through 2014, half-window widths are narrow, edgeAdjust option was used, and data are calculated on a 9-month rather than an annual basis. Wide half-window widths are 20 for years, 2 log cycles for discharge, and 0.5 for season. Narrow half-window widths are 7 for years, 2 log cycles for discharge, and 0.25 for season. 


\section{Summary}

The U.S. Geological Survey, in cooperation with the New England Interstate Water Pollution Control Commission and the Vermont Department of Environmental Conservation, updated estimates of daily and 9-month concentrations and fluxes, based both on observed and flow-normalized discharges, of total and dissolved phosphorus, total nitrogen ("nitrogen"), chloride, and total suspended solids (TSS) for 18 tributaries of Lake Champlain. Estimates for total and dissolved phosphorus and chloride are for 1991 through 2014 and for nitrogen and TSS are for 1993 through 2014. A primary use of the total phosphorus estimates is to evaluate progress towards meeting phosphorus-reduction goals for loads entering Lake Champlain from its tributaries, as called for in the Lake management plan, "Opportunities for Action." The Weighted Regressions on Time, Discharge, and Season (WRTDS) regression model was used to make all estimates, which are provided in Medalie (2016). The percent change in annual concentration and flux is provided for two time periods: the full record between 1991 (or 1993) and 2014 and the recent record between 2000 and 2014. Uncertainty in the trend estimate, calculated by using the R package EGRETci, is presented as an estimate of the statistical probability or likelihood of an increasing or decreasing trend for the full record.

The report describes several differences in model specification and function compared to previous studies that used WRTDS to estimate concentrations and fluxes using data from Lake Champlain tributaries. Discharge and water-quality data used in the model were directly obtained from online databases. While default half-window widths were used for time and discharge, the half-window width for season was narrowed from the default of 0.5 to 0.25 of a year for this study to address sparse and nonrepresentative sample collection in winter. To reduce potential bias from model extrapolations beyond available data, estimated daily and annual estimates and trends based on annual estimates presented in this report and in Medalie (2016) are for the 9-month reporting period of March through November. Winter data are used to compute the average fraction of total annual flux contributed during winter.

The statistic used to assess potential bias shows that WRTDS flux models are acceptable for 68 out of 72 models for total and dissolved phosphorus, nitrogen, and chloride. As found in previous studies, the potential for biased TSS flux models is larger than for other constituents in the Lake Champlain tributaries. Plots of observed in relation to estimated flux for four representative models with large flux bias statistics show overall symmetry around the 1:1 line at highest observed or estimated fluxes, which indicates that model bias is not a substantial problem.

Median winter-to-annual fractions ranged between 21 percent for total suspended solids and 27 percent for dissolved phosphorus. The winter contribution for all constituents was consistently largest from the Mettawee River and smallest from the Ausable River.

Over the full record, 6 tributaries had decreasing trends in concentrations of total phosphorus, and 12 had increasing trends. Trends in concentrations of dissolved phosphorus decreased in 6 and increased in 8 tributaries, trends in concentrations of nitrogen decreased in 10 and increased in 4 tributaries, trends in concentrations of chloride decreased in 2 and increased in 15 tributaries, and trends in concentrations of TSS decreased in 4 and increased in 8 tributaries. Trends in flux of total phosphorus between 1991 and 2014 decreased in 5 tributaries and increased in 10; for flux of dissolved phosphorus, trends decreased in 4 and increased in 10 tributaries; and for flux of chloride, trends decreased in 2 and increased in 15 tributaries. Trends in flux of nitrogen between 1993 and 2014 decreased in 10 and increased in 4 tributaries, and for flux of TSS, trends decreased in 3 and increased in 11 tributaries.

For concentrations of total phosphorus, a positive percent change in the Lamoille River for the full record changed to a negative percent change for the recent record, a negative percent change in the 
Little Chazy River for the full record grew more negative by a factor of 5 in the recent record, and a negative percent change in the LaPlatte River diminished and a positive percent change in Little Otter Creek increased in the recent record compared to the full record. For flux of total phosphorus, positive percent changes in the Great Chazy, Little Chazy, and Ausable Rivers for the full record shifted to negative percent changes in the recent record; and negative percent changes in the Missisquoi and Pike Rivers for the full record shifted to positive percent changes in the recent record. Although caution must be used in comparing the magnitudes and directions of percent changes from this report with those from previous reports because the time intervals are not completely synchronous, there are more similarities than differences in this comparison for both concentration and flux.

Concentration estimates of total phosphorus in the Winooski River were used to examine changes in long-term trend direction between this and a previous study and, specifically, to explore whether changes were due to differences in model specifications or differences from 4 years of additional data. This report shows that if all model specifications were kept equal, concentration estimates increased from 2010 to 2014; that the edgeAdjust algorithm used in the current study served to smooth the flow-normalized data; that narrowing the half-window widths increased scatter; and that the change from an annual to a 9-month basis by omitting winter estimates changed a few individual points but not the overall shape of the flow-normalized curve. Similar testing of other tributaries showed that the effect of decreasing half-window widths and omitting 3 months from annual estimates of concentration and flux was generally to increase scatter over time. The analysis of 4 more years of data than in previous studies resulted, for some of the tributaries, in reversals of trend direction that were not related to changes in model specification or function.

\section{References Cited}

Hirsch, R.M., 2014, Large biases in regression-based constituent flux estimates - Causes and diagnostic tools: Journal of the American Water Resources Association, v. 50, no. 6, p. 1401-1424, accessed May 22, 2014, at http://onlinelibrary.wiley.com/doi/10.1111/jawr.12195/full.

Hirsch, R.M., 2015, EGRETextra/vignettes/SeasonalFraction.Rmd: GitHub, Inc., USGS-R repository Web page, accessed July 13, 2016, at https://github.com/USGS-

R/EGRETextra/blob/master/vignettes/SeasonalFraction.Rmd.

Hirsch, R.M., Archfield, S.A., and De Cicco, L.A., 2015, A bootstrap method for estimating uncertainty of water quality trends: Environmental Modelling \& Software, v. 73, p. 148-166, accessed September 29, 2015, at http://dx.doi.org/10.1016/j.envsoft.2015.07.017.

Hirsch, R.M., and De Cicco, L.A., 2014, User guide to Exploration and Graphics for RivEr Trends (EGRET) and dataRetrieval—R packages for hydrologic data (version 2.0, February 2015):

U.S. Geological Survey Techniques and Methods book 4, chap. A10, 93 p., accessed February 10, 2015, at http://dx.doi.org/10.3133/tm4A10.

Hirsch, R.M., Moyer, D.L., and Archfield, S.A., 2010, Weighted regressions on time, discharge, and season (WRTDS) with an application to Chesapeake Bay river inputs: Journal of the American Water Resources Association (JAWRA), v. 46, no. 5, p. 857-880, accessed October 30, 2012, at http://onlinelibrary.wiley.com/doi/10.1111/j.1752-1688.2010.00482.x/abstract.

Lake Champlain Basin Program, 2014, Opportunities for action-An evolving plan for the future of the Lake Champlain Basin: Lake Champlain Basin Program Web page, accessed April 28, 2014, at http://plan.lcbp.org/.

Medalie, Laura, 2013, Concentration, flux, and the analysis of trends of total and dissolved phosphorus, total nitrogen, and chloride in 18 tributaries to Lake Champlain, Vermont and New York, 1990-2011: 
U.S. Geological Survey Scientific Investigations Report 2013-5021, 29 p., accessed June 1, 2016, at http://pubs.usgs.gov/sir/2013/5021/.

Medalie, Laura, 2014, Concentration and flux of total and dissolved phosphorus, total nitrogen, chloride, and total suspended solids for monitored tributaries of Lake Champlain, 1990-2012: U.S. Geological Survey Open-File Report 2014-1209, 21 p., accessed June 1, 2016, at http://dx.doi.org/10.3133/ofr20141209.

Medalie, Laura, 2016, Estimates of annual and daily concentration and flux of nutrients, chloride, and total suspended solids in tributaries of Lake Champlain, 1990 through 2014: U.S. Geological Survey data release, accessed December 2016 at https://doi.org/10.5066/F7RN360M.

Medalie, Laura, Hirsch, R.M., and Archfield, S.A., 2012, Use of flow-normalization to evaluate nutrient concentration and flux changes in Lake Champlain tributaries, 1990-2009: Journal of Great Lakes Research, v. 38, supplement 1, p. 58-67., accessed June 1, 2016, at http://dx.doi.org/10.1016/j.jglr.2011.10.002.

Moyer, D.L., Hirsch, R.M., and Hyer, K.E., 2012, Comparison of two regression-based approaches for determining nutrient and sediment fluxes and trends in the Chesapeake Bay watershed: U.S. Geological Survey Scientific Investigations Report 2012-5244, 118 p., accessed June 1, 2016, at http://pubs.usgs.gov/sir/2012/5244/.

Québec Ministère du Développement durable, de l'Environnement et de la Lutte contre les changements climatiques, 2015, Fiche signalétique de la station 030424: Centre d'expertise hydrique du Québec Hydrometric Network level and flow history station database, accessed October 15, 2015, at http://www.cehq.gouv.qc.ca/hydrometrie/historique donnees/fiche station.asp?NoStation=030424.

Vermont Department of Environmental Conservation and New York State Department of Environmental Conservation, 2015, Long-term water quality and biological monitoring project for Lake Champlain -2015 quality assurance project plan, revision 1.3: Vermont Department of Environmental Conservation Web page, accessed October 28, 2015, at http://dec.vermont.gov/watershed/lakes-ponds/monitor/lake-champlain. 
Table 1. Station identifiers and start and end dates of daily and 9-month estimates and of trend period for concentration and flux of total and dissolved phosphorus, chloride, total nitrogen, and total suspended solids for 18 monitored tributaries of Lake Champlain.

[Little Chazy River and Putnam Creek were discontinued on October 1, 2014. USGS, U.S. Geological Survey; MDDELCC, Ministère du Développement durable, de l'Environnement et la Lutte contre les changements climatiques (Ministry of Sustainable Development, Environment and the Fight against Climate Change); STORET, U.S. Environmental Protection Agency STOrage and RETrieval database]

\begin{tabular}{|c|c|c|c|c|c|c|c|c|c|c|}
\hline \multirow{3}{*}{ Tributary } & \multirow{3}{*}{$\begin{array}{l}\text { USGS or } \\
\text { Quebec } \\
\text { MDDELCC } \\
\text { streamgage } \\
\text { number }\end{array}$} & \multirow{3}{*}{$\begin{array}{l}\text { STORET } \\
\text { station } \\
\text { identifier }^{1}\end{array}$} & \multicolumn{3}{|c|}{$\begin{array}{l}\text { Total and dissolved phosphorus and } \\
\text { chloride }\end{array}$} & \multicolumn{3}{|c|}{ Total nitrogen and total suspended solids } & \multicolumn{2}{|c|}{ All constituents } \\
\hline & & & \multirow[b]{2}{*}{$\begin{array}{c}\text { First day of } \\
\text { daily estimate }\end{array}$} & \multicolumn{2}{|c|}{ First year } & \multirow[b]{2}{*}{$\begin{array}{c}\text { First day of } \\
\text { daily estimate }\end{array}$} & \multicolumn{2}{|c|}{ First year } & \multirow[b]{2}{*}{$\begin{array}{l}\text { Last day of daily } \\
\text { estimate }\end{array}$} & \multirow{2}{*}{$\begin{array}{l}\text { Last year of } 9 \\
\text { month } \\
\text { estimate and } \\
\text { trend period }\end{array}$} \\
\hline & & & & $\begin{array}{l}\text { 9-month } \\
\text { estimate }\end{array}$ & $\begin{array}{l}\text { Trend } \\
\text { period }\end{array}$ & & $\begin{array}{l}\text { 9-month } \\
\text { estimate }\end{array}$ & $\begin{array}{l}\text { Trend } \\
\text { period }\end{array}$ & & \\
\hline Great Chazy & 04271500 & 500492 & 1-Mar-1990 & 1990 & 1991 & 1-Jun-1992 & 1993 & 1993 & 30-Nov-2014 & 2014 \\
\hline Little Chazy & 04271815 & 500490 & 1-Mar-1990 & 1990 & 1991 & 1-Jun-1992 & 1993 & 1993 & 30-Sep-2014 & 2013 \\
\hline Saranac & 04273500 & 500491 & 1-Mar-1990 & 1990 & 1991 & 1-Jun-1992 & 1993 & 1993 & 30-Nov-2014 & 2014 \\
\hline Salmon & 04273700 & 500502 & 1-Mar-1990 & 1990 & 1991 & 1-Jun-1992 & 1993 & 1993 & 30-Nov-2014 & 2014 \\
\hline Little Ausable & 04273800 & 500501 & 1-Oct-1991 & 1992 & 1992 & 1-Jun-1992 & 1993 & 1993 & 30-Nov-2014 & 2014 \\
\hline Ausable & 04275500 & 500500 & 1-Mar-1990 & 1990 & 1991 & 1-Jun-1992 & 1993 & 1993 & 30-Nov-2014 & 2014 \\
\hline Bouquet & 04276500 & 500498 & 1-Mar-1990 & 1990 & 1991 & 1-Jun-1992 & 1993 & 1993 & 30-Nov-2014 & 2014 \\
\hline Putnam & 04276842 & 500495 & 1-Mar-1990 & 1990 & 1991 & 1-Jun-1992 & 1993 & 1993 & 30-Sep-2014 & 2013 \\
\hline Poultney & 04280000 & 500578 & 1-Mar-1990 & 1990 & 1991 & 1-Jun-1992 & 1993 & 1993 & 30-Nov-2014 & 2014 \\
\hline Mettawee & 04280450 & 500508 & 1-Mar-1990 & 1990 & 1991 & 1-Jun-1992 & 1993 & 1993 & 30-Nov-2014 & 2014 \\
\hline Otter & 04282500 & 500509 & 1-Mar-1990 & 1990 & 1991 & 1-Jun-1992 & 1993 & 1993 & $30-$ Nov-2014 & 2014 \\
\hline Little Otter & 04282650 & 501371 & 1-Mar-1990 & 1990 & 1991 & 1-Jun-1992 & 1993 & 1993 & 30-Nov-2014 & 2014 \\
\hline Lewis & 04282780 & 500503 & 1-Mar-1990 & 1990 & 1991 & 1-Jun-1992 & 1993 & 1993 & 30-Nov-2014 & 2014 \\
\hline LaPlatte & 04282795 & 501594 & 1-Mar-1990 & 1990 & 1991 & 1-Jun-1992 & 1993 & 1993 & 30-Nov-2014 & 2014 \\
\hline Winooski & 04290500 & 501903 & 1-Mar-1990 & 1990 & 1991 & 1-Jun-1992 & 1993 & 1993 & 30-Nov-2014 & 2014 \\
\hline Lamoille & 04292500 & 501794 & 1-Mar-1990 & 1990 & 1991 & 1-Jun-1992 & 1993 & 1993 & 30-Nov-2014 & 2014 \\
\hline Missisquoi & 04294000 & 500505 & 1-Mar-1990 & 1990 & 1991 & 1-Jun-1992 & 1993 & 1993 & 30-Nov-2014 & 2014 \\
\hline Pike & 030424 & 500512 & 1-Mar-1990 & 1990 & 1991 & 1-Jun-1992 & 1993 & 1993 & 30-Nov-2014 & 2014 \\
\hline
\end{tabular}

${ }^{1}$ To retrieve water-quality records from these stations from STORET, or by using the command "readWQPqw" from the R dataRetrieval package (Hirsch and De Cicco, 2014), append "1VTDECWQ-" in front of the 6-digit number. 
Table 2. Flux bias statistics comparing the Weighted Regression on Time, Discharge, and Season regression model estimates with water-quality observations for total and dissolved phosphorus, total nitrogen, chloride, and total suspended solids for tributaries to Lake Champlain.

[Flux bias statistics greater than \pm 0.1 are shown in bold typeface and indicate a potentially biased regression model. The Weighted Regression on Time, Discharge, and Season regression model is from Hirsch and others (2010)]

\begin{tabular}{|c|c|c|c|c|c|}
\hline Tributary & Total phosphorus & $\begin{array}{c}\text { Dissolved } \\
\text { phosphorus }\end{array}$ & Total nitrogen & Chloride & Total suspended solids \\
\hline Great Chazy & -0.012 & 0.000 & 0.006 & -0.016 & 0.179 \\
\hline Little Chazy & -0.029 & -0.028 & 0.011 & -0.010 & 0.053 \\
\hline Saranac & -0.236 & -0.188 & -0.020 & -0.020 & -0.677 \\
\hline Salmon & -0.031 & -0.085 & -0.007 & 0.018 & 0.123 \\
\hline Little Ausable & -0.072 & -0.027 & 0.025 & -0.017 & 0.129 \\
\hline Ausable & 0.027 & -0.049 & -0.025 & -0.020 & 0.234 \\
\hline Bouquet & 0.076 & 0.094 & 0.095 & -0.028 & 0.416 \\
\hline Putnam & -0.138 & -0.029 & -0.044 & -0.035 & -0.018 \\
\hline Poultney & -0.001 & -0.006 & -0.018 & -0.010 & 0.119 \\
\hline Mettawee & 0.074 & 0.011 & -0.003 & -0.005 & 0.213 \\
\hline Otter & -0.018 & 0.003 & -0.016 & -0.011 & 0.023 \\
\hline Little Otter & -0.012 & 0.000 & 0.009 & -0.014 & 0.042 \\
\hline Lewis & -0.022 & -0.102 & -0.012 & -0.004 & 0.098 \\
\hline LaPlatte & 0.052 & 0.091 & 0.011 & -0.003 & 0.123 \\
\hline Winooski & 0.033 & -0.017 & -0.007 & -0.022 & 0.167 \\
\hline Lamoille & -0.058 & 0.030 & -0.006 & -0.019 & -0.107 \\
\hline Missisquoi & -0.011 & 0.015 & -0.021 & -0.017 & 0.084 \\
\hline Pike & -0.010 & 0.025 & -0.051 & -0.013 & 0.025 \\
\hline
\end{tabular}


Table 3. Average fraction of annual flux contributed during winter months for tributaries to Lake Champlain. [Winter consists of December, January, and February; percentages greater than 30 are shown in bold typeface]

\begin{tabular}{|c|c|c|c|c|c|}
\hline \multirow[b]{2}{*}{ Tributary } & \multicolumn{5}{|c|}{ Percent of annual flow-normalized flux } \\
\hline & Total phosphorus & $\begin{array}{c}\text { Dissolved } \\
\text { phosphorus }\end{array}$ & Total nitrogen & Chloride & Total suspended solids \\
\hline Little Chazy & 29 & 32 & 24 & 21 & 22 \\
\hline Saranac & 20 & 21 & 24 & 29 & 15 \\
\hline Salmon & 18 & 25 & 24 & 26 & 10 \\
\hline Little Ausable & 26 & 28 & 26 & 24 & 17 \\
\hline Ausable & 19 & 20 & 19 & 21 & 16 \\
\hline Bouquet & 20 & 29 & 22 & 22 & 15 \\
\hline Putnam & 31 & 23 & 24 & 23 & 26 \\
\hline Poultney & 30 & 33 & 33 & 26 & 24 \\
\hline Mettawee & 38 & 34 & 35 & 29 & 36 \\
\hline Otter & 33 & 31 & 32 & 26 & 29 \\
\hline Little Otter & 31 & 27 & 32 & 29 & 30 \\
\hline Lewis & 26 & 28 & 28 & 25 & 21 \\
\hline Winooski & 18 & 21 & 25 & 25 & 16 \\
\hline Lamoille & 18 & 27 & 23 & 21 & 14 \\
\hline Missisquoi & 22 & 25 & 24 & 22 & 21 \\
\hline Pike & 29 & 26 & 27 & 24 & 27 \\
\hline
\end{tabular}


Table 4. Trend estimates for concentration of total and dissolved phosphorus, total nitrogen, chloride, and total suspended solids for two time periods, and trend probabilities between 1991 (or 1993) and 2014 for tributaries to Lake Champlain.

[Percent change per year shows changes for flow-normalized concentration; trend probability shows the statistical probability or likelihood of an increasing (black up arrow) or decreasing (green down arrow) trend; "--" and "NT" for trend direction and probability indicate no trend (that is, an upward trend is about as likely as a downward trend); a grayed result indicates that although the calculated percent change per year has a negative or no sign (for a positive result), the overall probability is for no trend]

\begin{tabular}{|c|c|c|c|c|c|c|c|c|c|c|c|c|}
\hline \multirow{3}{*}{ Tributary } & \multicolumn{4}{|c|}{ Total phosphorus } & \multicolumn{4}{|c|}{ Dissolved phosphorus } & \multicolumn{4}{|c|}{ Total nitrogen } \\
\hline & \multicolumn{2}{|c|}{ Percent change per year } & \multicolumn{2}{|c|}{ Trend, 1991-2014 } & \multicolumn{2}{|c|}{ Percent change per year } & \multicolumn{2}{|c|}{ Trend, 1991-2014 } & \multicolumn{2}{|c|}{ Percent change per year } & \multicolumn{2}{|c|}{ Trend, 1993-2014 } \\
\hline & $2000-14$ & 1991-2014 & Direction & Probability & $2000-14$ & 1991-2014 & Direction & Probability & $2000-14$ & 1993-2014 & Direction & Probability \\
\hline Great Chazy & -0.07 & 0.95 & $\uparrow$ & 0.9 & -0.65 & 0.3 & $\uparrow$ & 0.72 & -0.73 & -0.82 & $\downarrow$ & 0.99 \\
\hline Little Chazy $^{1}$ & -2.6 & -0.48 & $\downarrow$ & 0.74 & -3.2 & -0.85 & $\downarrow$ & 0.89 & -2.3 & -1.3 & $\downarrow$ & 0.99 \\
\hline Saranac & 0.7 & 0.95 & $\uparrow$ & 0.99 & 1.3 & 1.9 & $\uparrow$ & 0.96 & -1.9 & -1.4 & $\downarrow$ & 0.99 \\
\hline Salmon & 1.3 & 1.2 & $\uparrow$ & 0.97 & -0.18 & 0.48 & - & NT & -1.8 & -1.5 & $\downarrow$ & 0.99 \\
\hline Little Ausable ${ }^{2}$ & -1.9 & -1.1 & $\downarrow$ & 0.82 & -2.2 & -0.6 & $\downarrow$ & 0.79 & -0.3 & 0.26 & - & NT \\
\hline Ausable & -0.03 & 0.53 & $\uparrow$ & 0.87 & 0.19 & 0.6 & $\uparrow$ & 0.87 & -2.2 & -1.3 & $\downarrow$ & 0.96 \\
\hline Bouquet & -0.02 & 0.49 & $\uparrow$ & 0.74 & 0.76 & 2.4 & $\uparrow$ & 0.99 & -2.3 & -1.6 & $\downarrow$ & 0.95 \\
\hline Putnam ${ }^{1}$ & 0.61 & 1.7 & $\uparrow$ & 0.99 & 2.9 & 3.5 & $\uparrow$ & 0.99 & -1.7 & -1.4 & $\downarrow$ & 0.99 \\
\hline Poultney & 0.54 & 0.44 & $\uparrow$ & 0.82 & 0.84 & 0.13 & - & NT & -1.3 & -0.88 & $\downarrow$ & 0.99 \\
\hline Mettawee & 0.99 & 0.45 & $\uparrow$ & 0.93 & 0.13 & 1.9 & $\uparrow$ & 0.99 & -1.1 & -0.52 & $\downarrow$ & 0.9 \\
\hline Otter & -0.77 & -1.7 & $\downarrow$ & 0.99 & -0.23 & -2.3 & $\downarrow$ & 0.99 & -0.26 & -0.28 & - & NT \\
\hline Little Otter & 3 & 1.8 & $\uparrow$ & 0.99 & 0.95 & 0.2 & - & NT & 0.67 & 0.92 & $\uparrow$ & 0.95 \\
\hline Lewis & 1.7 & 1.5 & $\uparrow$ & 0.97 & 0.43 & 0.26 & - & NT & -0.37 & 0.34 & $\uparrow$ & 0.89 \\
\hline LaPlatte & -1.6 & -3.3 & $\downarrow$ & 0.99 & -2.5 & -3.7 & $\downarrow$ & 0.99 & -1.8 & -1.7 & $\downarrow$ & 0.99 \\
\hline Winooski & 1.5 & 0.56 & $\uparrow$ & 0.76 & 1.1 & -0.26 & $\downarrow$ & 0.83 & -0.09 & 0.74 & $\uparrow$ & 0.97 \\
\hline Lamoille & -0.83 & 0.54 & $\uparrow$ & 0.86 & 0.57 & 1.1 & $\uparrow$ & 0.82 & -0.7 & -0.23 & - & NT \\
\hline Missisquoi & -0.11 & -0.19 & $\downarrow$ & 0.74 & 1.3 & 0.77 & $\uparrow$ & 0.87 & -0.4 & 0.19 & $\uparrow$ & 0.71 \\
\hline \multirow[t]{2}{*}{ Pike } & -1.7 & -1.8 & $\downarrow$ & 0.97 & -2.4 & -2.3 & $\downarrow$ & 0.99 & -1.3 & -0.2 & - & NT \\
\hline & \multicolumn{4}{|c|}{ Chloride } & \multicolumn{4}{|c|}{ Total suspended solids } & & & & \\
\hline \multirow[t]{2}{*}{ Tributary } & \multicolumn{2}{|c|}{ Percent change per year } & \multicolumn{2}{|c|}{ 1991-2014, trend } & \multicolumn{2}{|c|}{ Percent change per year } & \multicolumn{2}{|c|}{ 1993-2014, trend } & & & & \\
\hline & $2000-14$ & 1991-2014 & Direction & Probability & $2000-14$ & 1993-2014 & Direction & Probability & & & & \\
\hline Great Chazy & 0.08 & 0.94 & $\uparrow$ & 0.99 & -1.1 & 0.11 & - & NT & & & & \\
\hline Little Chazy $^{1}$ & -0.02 & 0.67 & $\uparrow$ & 0.89 & -0.56 & -0.03 & - & NT & & & & \\
\hline Saranac & 2.8 & 5.4 & $\uparrow$ & 0.99 & 0.44 & 0.7 & $\uparrow$ & 0.88 & & & & \\
\hline Salmon & 3.3 & 4.1 & $\uparrow$ & 0.99 & -0.53 & -0.2 & - & NT & & & & \\
\hline Little Ausable ${ }^{2}$ & 1.3 & 2.3 & $\uparrow$ & 0.99 & -1.7 & -0.48 & $\downarrow$ & 0.72 & & & & \\
\hline Ausable & 0.24 & 4.1 & $\uparrow$ & 0.99 & -1.3 & -0.07 & - & NT & & & & \\
\hline Bouquet & -0.34 & 2.1 & $\uparrow$ & 0.99 & -1.3 & -0.38 & $\downarrow$ & 0.67 & & & & \\
\hline Putnam ${ }^{1}$ & 0.83 & 2.7 & $\uparrow$ & 0.99 & -0.25 & -0.26 & - & NT & & & & \\
\hline Poultney & -0.61 & 0.5 & $\uparrow$ & 0.97 & 3.4 & 3.3 & $\uparrow$ & 0.94 & & & & \\
\hline Mettawee & 1.6 & 3.6 & $\uparrow$ & 0.99 & 0.26 & -0.27 & - & NT & & & & \\
\hline Otter & 0.37 & 1.5 & $\uparrow$ & 0.99 & 0.84 & 1.1 & $\uparrow$ & 0.77 & & & & \\
\hline Little Otter & -0.6 & 0.73 & $\uparrow$ & 0.97 & 17 & 16 & $\uparrow$ & 0.98 & & & & \\
\hline Lewis & -0.35 & 0.44 & $\uparrow$ & 0.91 & 3.6 & 7.6 & $\uparrow$ & 0.98 & & & & \\
\hline LaPlatte & -3.4 & -2.2 & $\downarrow$ & 0.99 & 1.4 & 2.3 & $\uparrow$ & 0.89 & & & & \\
\hline Winooski & 0.31 & 2 & $\uparrow$ & 0.99 & 3.5 & 1.1 & $\uparrow$ & 0.87 & & & & \\
\hline Lamoille & 0.16 & 0.22 & - & NT & -1.4 & -0.48 & $\downarrow$ & 0.7 & & & & \\
\hline Missisquoi & -0.54 & 0.19 & $\uparrow$ & 0.86 & 0.19 & -0.14 & $\downarrow$ & 0.67 & & & & \\
\hline Pike & -1.1 & -0.47 & $\downarrow$ & 0.96 & -0.52 & 1.6 & $\uparrow$ & 0.72 & & & & \\
\hline
\end{tabular}

${ }^{1}$ Last year of trend period is 2013

${ }^{2}$ First year of trend period for total and dissolved phosphorus and chloride is 1992. 
Table 5. Trend estimates for flux of total and dissolved phosphorus, total nitrogen, chloride, and total suspended solids for two time periods, and trend probabilities between 1991 (or 1993) and 2014 for tributaries to Lake Champlain.

[Percent change per year shows changes for flow-normalized flux; trend probability shows the statistical probability or likelihood of an increasing (black up arrow) or decreasing (green down arrow) trend; "--" and "NT" for trend direction and probability indicate no trend (that is, an upward trend is about as likely as a downward trend); a grayed result indicates that although the calculated percent change per year has a negative or no sign (for a positive result), the overall probability is for no trend]

\begin{tabular}{|c|c|c|c|c|c|c|c|c|c|c|c|c|}
\hline \multirow{3}{*}{ Tributary } & \multicolumn{4}{|c|}{$\begin{array}{l}\text { Total phosphorus } \\
\end{array}$} & \multicolumn{4}{|c|}{ Dissolved phosphorus } & \multicolumn{4}{|c|}{ Total nitrogen } \\
\hline & \multicolumn{2}{|c|}{ Percent change per year } & \multicolumn{2}{|c|}{ Trend, 1991-2014 } & \multicolumn{2}{|c|}{ Percent change per year } & \multicolumn{2}{|c|}{ Trend, 1991-2014 } & \multicolumn{2}{|c|}{ Percent change per year } & \multicolumn{2}{|c|}{ Trend, 1993-2014 } \\
\hline & $2000-14$ & $1991-2014$ & Direction & Probability & $2000-14$ & $1991-2014$ & Direction & Probability & $2000-14$ & 1993-2014 & Direction & Probability \\
\hline Great Chazy & -0.18 & 0.17 & - & NT & -0.08 & 0.44 & $\uparrow$ & 0.77 & -0.29 & -0.49 & $\downarrow$ & 0.84 \\
\hline Little Chazy $^{1}$ & -0.5 & 0.39 & $\uparrow$ & 0.74 & -1.1 & 0.11 & - & NT & -1.3 & -0.57 & $\downarrow$ & 0.84 \\
\hline Saranac & 1.5 & 1.4 & $\uparrow$ & 0.99 & 1.6 & 2.3 & $\uparrow$ & 0.99 & -1.6 & -1.1 & $\downarrow$ & 0.99 \\
\hline Salmon & 1.7 & 0.82 & $\uparrow$ & 0.90 & 1.5 & 1.5 & $\uparrow$ & 0.99 & -1.3 & -1.0 & $\downarrow$ & 0.99 \\
\hline Little Ausable ${ }^{2}$ & -0.36 & -0.99 & $\downarrow$ & 0.79 & -0.93 & -0.83 & - & NT & -0.29 & -0.17 & $\downarrow$ & 0.67 \\
\hline Ausable & -0.94 & 0.21 & - & NT & 1.1 & 1.7 & $\uparrow$ & 0.96 & -2.4 & -1.3 & $\downarrow$ & 0.90 \\
\hline Bouquet & -0.98 & -0.58 & $\downarrow$ & 0.84 & 0.74 & 2.2 & $\uparrow$ & 0.97 & -2.5 & -1.6 & $\downarrow$ & 0.92 \\
\hline Putnam ${ }^{1}$ & 1.5 & 1.5 & $\uparrow$ & 0.90 & 3.9 & 4.0 & $\uparrow$ & 0.99 & -0.65 & -0.85 & $\downarrow$ & 0.87 \\
\hline Poultney & 3.5 & 2.2 & $\uparrow$ & 0.97 & 1.4 & 0.35 & - & NT & -0.7 & -0.15 & - & NT \\
\hline Mettawee & 0.87 & 0.24 & $\uparrow$ & 0.73 & 0.46 & 1.1 & $\uparrow$ & 0.94 & -1.2 & -0.84 & $\downarrow$ & 0.97 \\
\hline Otter & -0.8 & -0.91 & $\downarrow$ & 0.89 & 0.37 & -1.5 & $\downarrow$ & 0.97 & -0.33 & -0.22 & - & NT \\
\hline Little Otter & 1.8 & 1.4 & $\uparrow$ & 0.99 & 1.5 & 0.66 & $\uparrow$ & 0.89 & 0.77 & 0.89 & $\uparrow$ & 0.93 \\
\hline Lewis & 2.5 & 1.3 & $\uparrow$ & 0.88 & 0.91 & -0.02 & - & NT & 0.35 & 0.79 & $\uparrow$ & 0.97 \\
\hline LaPlatte & -0.48 & -2.1 & $\downarrow$ & 0.99 & -1.7 & -3.2 & $\downarrow$ & 0.99 & -1.4 & -1.3 & $\downarrow$ & 0.97 \\
\hline Winooski & 2.9 & 1.3 & $\uparrow$ & 0.90 & 0.36 & -0.81 & $\downarrow$ & 0.90 & -0.03 & 0.44 & $\uparrow$ & 0.87 \\
\hline Lamoille & 0.1 & 0.93 & $\uparrow$ & 0.97 & 0.29 & 0.46 & $\uparrow$ & 0.70 & -0.49 & -0.12 & - & NT \\
\hline Missisquoi & 1.5 & -0.04 & $\downarrow$ & 0.67 & 1.7 & 0.91 & $\uparrow$ & 0.89 & 0.03 & 0.51 & $\uparrow$ & 0.91 \\
\hline \multirow[t]{2}{*}{ Pike } & 0.77 & -0.35 & - & NT & -0.9 & -1.0 & $\downarrow$ & 0.99 & -1.6 & -0.04 & - & NT \\
\hline & \multicolumn{4}{|c|}{ Chloride } & \multicolumn{4}{|c|}{ Total suspended solids } & & & & \\
\hline \multirow[t]{2}{*}{ Tributary } & \multicolumn{2}{|c|}{ Percent change per year } & \multicolumn{2}{|c|}{ 1991-2014, trend } & \multicolumn{2}{|c|}{ Percent change per year } & \multicolumn{2}{|c|}{ 1993-2014, trend } & & & & \\
\hline & $2000-14$ & 1991-2014 & Direction & Probability & $2000-14$ & 1993-2014 & Direction & Probability & & & & \\
\hline Great Chazy & 0.78 & 1.9 & $\uparrow$ & 0.99 & -0.64 & 0.18 & - & NT & & & & \\
\hline Little Chazy $^{1}$ & 0.92 & 1.3 & $\uparrow$ & 0.99 & 0.65 & 0.93 & $\uparrow$ & 0.72 & & & & \\
\hline Saranac & 2.8 & 5.6 & $\uparrow$ & 0.99 & 1.2 & 1.1 & $\uparrow$ & 0.90 & & & & \\
\hline Salmon & 2.6 & 3.7 & $\uparrow$ & 0.99 & 0.15 & 0.3 & - & NT & & & & \\
\hline Little Ausable ${ }^{2}$ & 1.2 & 1.9 & $\uparrow$ & 0.99 & -0.75 & -0.04 & $\downarrow$ & 0.70 & & & & \\
\hline Ausable & 0.13 & 4.0 & $\uparrow$ & 0.99 & -1.9 & -0.5 & $\downarrow$ & 0.70 & & & & \\
\hline Bouquet & -0.53 & 2.0 & $\uparrow$ & 0.99 & -1.7 & -0.36 & $\downarrow$ & 0.72 & & & & \\
\hline Putnam $^{1}$ & 0.36 & 2.9 & $\uparrow$ & 0.99 & 0.87 & 0.47 & - & NT & & & & \\
\hline Poultney & -0.59 & 0.46 & $\uparrow$ & 0.90 & 4.5 & 4.1 & $\uparrow$ & 0.86 & & & & \\
\hline Mettawee & 2.1 & 3.6 & $\uparrow$ & 0.99 & 1.4 & 1.1 & $\uparrow$ & 0.67 & & & & \\
\hline Otter & 0.28 & 1.3 & $\uparrow$ & 0.99 & 0.02 & 1.1 & $\uparrow$ & 0.82 & & & & \\
\hline Little Otter & -0.9 & 0.17 & - & NT & 7.7 & 7.7 & $\uparrow$ & 0.97 & & & & \\
\hline Lewis & -0.19 & 0.36 & $\uparrow$ & 0.85 & 3.2 & 7.1 & $\uparrow$ & 0.97 & & & & \\
\hline LaPlatte & -1.7 & -1.2 & 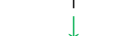 & 0.99 & 0.9 & 1.4 & $\uparrow$ & 0.74 & & & & \\
\hline Winooski & 0.42 & 1.7 & $\uparrow$ & 0.99 & 3.5 & 1.5 & $\uparrow$ & 0.87 & & & & \\
\hline Lamoille & 0.31 & 0.5 & $\uparrow$ & 0.99 & 0.01 & -0.03 & - & NT & & & & \\
\hline Missisquoi & -0.4 & 0.3 & $\uparrow$ & 0.90 & 2.0 & 1.3 & $\uparrow$ & 0.89 & & & & \\
\hline Pike & -1.2 & -0.79 & $\downarrow$ & 1.00 & 1.4 & 4.1 & $\uparrow$ & 0.79 & & & & \\
\hline
\end{tabular}

${ }^{1}$ Last year of trend period is 2013 .

${ }^{2}$ First year of trend period for total and dissolved phosphorus and chloride is 1992. 